\title{
Alternative Dispute Settlement Mechanisms: Towards Restorative Justice in Yucatán, Mexico
}

\author{
Carlos Alberto Macedonio Hernández, Lucely Martina Carballo Solís, \\ Melba Angelina Méndez Fernández, Edith Cisneros-Cohernour \\ Universidad Autónoma de Yucatán, Yucatán, México
}

\begin{abstract}
This article presents an analysis of a new reform in the process of criminal law dispute resolution in Mexico. It examines the characteristics, principles, strengths, and weaknesses of this process for the protection of human rights, as well as its implications. Findings of the study indicate that the inclusion in the Mexican constitution of alternative dispute resolution mechanisms contributes to strengthening of democracy, by favoring the participation of private wills in handling conflicts and exercising their rights to solve their conflicts without the intervention of state organisms. Participation in mediation is voluntary, confidential, flexible, neutral, impartial, equitable, law abiding, and honest.
\end{abstract}

Keywords: human rights, mediation, legal process, lawyers' preparation

\section{Introduction}

On June 18, 2008, the Official Journal of the Mexican Federation published a decree, in which Articles $16,17,18,19,20,21$, and 22 of the Mexican constitutions were amended in its fractions: Sections XXI and XXIII of Article 73, Section VII of Article 115, and Section XIII, Paragraph B, of Article 123. These changes are related to public security and criminal justice, establishing the foundations of the new criminal justice system of Mexico. This constitutional reform had a strong impact on the domestic legal order, as it meant a change not only in the regulatory field, but also regarding to the legal experience understood as the law in its sociological dimension.

The constitutional reform resulted in a new foundation for the system of administering justice in Mexico, since the second transitory article of the aforementioned reform forced the officials governing the Mexican states to rethink their legal systems and train members of the prosecution and judiciary, in order to meet the demands of society. This was caused generally in response to the demand for a more flexible procedure, less corruption, greater sense of justice, and also more transparency.

The adversarial criminal justice system is the process by which criminal proceedings have been developed

Carlos Alberto Macedonio Hernández, Juris Doctor, coordinator of the academic group (Multidisciplinary and Tridimensional Vision of the Law), College of Law, Universidad Autónoma de Yucatán.

Lucely Martina Carballo Solís, Master in Law, academic dean and member of the academic group (Multidisciplinary and Tridimensional Vision of the Law), College of Law, Universidad Autónoma de Yucatán.

Melba Angelina Méndez Fernández, Master in Law, member of the academic group (Multidisciplinary and Tridimensional Vision of the Law), College of Law, Universidad Autónoma de Yucatán.

Edith Cisneros-Cohernour, Ph.D., member of the academic group (Educational Administration and Policy), College of Education, Universidad Autónoma de Yucatán. 
under a democratic regime (Constantino, 2009). The trial begins only by accusation of the victim and his/her family, the accuser is someone other than the judge, and the decision acts correspond to a state representative. It can be said that in this system, the representative of the state is on charge of the prosecution. If this action is not realized, it cannot be the source of the process. The freedom of people is ensured by a set of legally instituted guarantees. The only the exceptions are those allowed by the procedural needs. Therefore, there are some principles prevailing: equality, oral trial, public, and the concentration of procedural acts.

In the adversarial criminal proceedings, the defense has the freedom to offer evidence and its evaluation is responsibility of the judge, the hearings are public and oral, and the judge has an obligation to solve the conflict based on the evidence of sound system.

Based on the above, the processes from prosecution, defense, and the adversarial system decision-making are not exercised by a single person, but are entrusted to different subjects: The indictments are responsibility of the state prosecutor, defense acts to the accused, ${ }^{1}$ and acts of decision-making to the individual judge or magistrate among others.

The new adversarial system was created since March 13, 2007, when the president of Mexico, Felipe Calderon Hinojosa, proposed a criminal reform to the Senate that declared the principles in favor of an oral adversarial criminal justice system. This initiative was subjected to the opinion of the House on December 10, 2007, and approved the final draft of the reform on February 28, 2008. This, in turn, was also approved by local legislatures without modifications.

Finally, the constitutional reform in Criminal Justice and Public Safety was published in the National Official Gazette on June 18, 2008, resulting from transcendental importance in the field of justice administration, the implementation of the new oral penal accusatory process. This reform modified 10 articles of the constitution in order to change the system of administrating justice and the systems and institutions that surround it.

The centerpiece of the constitutional reform is to establish oral trials in criminal matters, that is, changing the mixed criminal justice system that Mexico had in its adversarial criminal proceedings, in order to ensure a higher level of legal certainty for the governed through the advertising, the immediacy, and the presumption of innocence. Article 20 of the Mexican Constitution states:

The process is adversarial and oral. It will be ruled by the principles of openness, contradiction, concentration, continuity, and immediacy.

A. General Principles:

I. The criminal proceedings have the purpose of clarifying facts, protecting the innocent, ensuring that the guilty not go unpunished and that the damage caused by the offense is repaired. (Gobierno Federal, 1917, p. 13)

It is noteworthy that the respect for human rights is vital in these reforms, because the public power limits are imposed to prevent abuses. In this regard, the rules of due process include the presumption of innocence, which prevents the abuse of preventive detention to allow the accused subject to criminal proceedings experience the process freely.

The reform also sought to end the monopoly hitherto exercised by the public prosecutor to establish that in certain cases resort to the offended judge directly through private action of the victim. Alternative dispute

1 ... Either personally or through an advocate, who represents the defender. This can be designated by the individual or appointed on its behalf by the state, and is called the public defender. 
resolution mechanisms are established to enable the parties to resolve their differences without a trial, through conciliation and mediation. $^{2}$

\section{The Alternative Dispute Resolution}

The counterpart of oral trials is the alternative means of dispute resolution, which is a way to avoid trial. For years, the institutions responsible for administering justice have exceeded their capacity for resolving disputes that the parties involved in a conflict of criminal law require, this is why the courts are full of old records and consequently procedural terms are not met.

This lag could not abate despite increasing the number of courts and judges. In addition, the minority of the population have financial resources and time to engage in a criminal law procedure that sometimes takes years. Because of the time lost and money spent, many of those affected are disappointed by our current criminal justice system. They waive any right they have to bring a lawsuit and wait for the judge to make a judgment, which in turn can be combated by the other party by an appeal or an injunction, meaning more lost time and more money spent. Given the above, it is very important that each and every one of the states has alternative means of dispute resolution.

With the amendment published on June 18, 2008, in the National Official Gazette, our constitution formally incorporated alternative dispute resolution mechanisms in Articles 17 and 18. The fourth paragraph of Article 17 states, "The laws provide for alternative dispute resolution mechanisms. In criminal matters they regulate their implementation, ensure the repair of the damage and establish the cases in which judicial review is required" (Gobierno Federal, 2016, p. 12).

Article 18 states, “... The alternative forms of justice should be observed in implementing of this system, as soon as they proceed ..." (Gobierno Federal, 2016, p. 12).

The inclusion in our constitution of alternative dispute resolution mechanisms contributes to strengthening of democracy, by favoring the participation of private wills in handling conflicts and exercising the right they have to solve them without the intervention of state organisms.

In Yucatán, the State Congress issued on June 24, 2009, the Law Alternative Dispute Resolution Mechanisms of Yucatán, in which it is stated that alternative means to judicial process are intended to resolve and settle disputes arising between rulers, achieving on one hand that conflicts are solved optimally as possible, and on the other hand, that the administration of justice is prompt, efficient, and effective, venting the workload in the courts as this has hindered the proper application of the law, so that the incorporation of the legal forms of conciliation and mediation as alternative means of trials in all types of court proceedings contributes to strengthening the organs of administering justice.

Article 179 of the Criminal Procedure Code for the State of Yucatán states, "In criminal cases are applicable, both conciliation and mediation as outlined in the Law Alternative Dispute Resolution Mechanisms of Yucatán" established by Article 181, "The request of submitting a criminal conflict to an alternative dispute resolution mechanism may take place at any stage, even having a final judgment, but in the latter case, it can only tried as conducive for repairing the damage" (Gobierno del Estado de Yucatán, 2011, p. 145).

\footnotetext{
${ }^{2}$ Constantine (2009) stated that the general objectives of a democratic system of criminal justice is to streamline justice through alternative means to the courts, private action, early termination, guaranteeing the right of defense, due process and rescue rights of victims and others (p. 23).
} 
In the case of criminal disputes that are likely to undergo some alternative mechanism, the prosecution during the investigation, or when appropriate, the presiding judge in the hearing process linkage shall inform the defendant accused and the victim on the possibility of some alternative mechanism. If they agree to resolve the penal conflict in this way, the public prosecutor or judge, as appropriate, shall suspend the investigation or prosecution for a period of 30 working days, extendable for 15 days, at the request of the parties, in terms of the law of matter (Gobierno del Estado de Yucatán, 2011, p. 126).

According to Peña (2010a), alternative mechanisms are "those procedures to settle disputes, avoiding the recourses of the 'official' or traditional system." The goal of alternative means of dispute resolution is that the courts will reduce the amount of workload they have, reduce cost and delay in resolving conflicts by getting them resolved in less time and with greater satisfaction of the parties, since they are the ones who proposed, negotiated, and agreed to the solutions to their problems.

These mechanisms have the advantage of having a solution in a short time. In Yucatán, according to Article 181 of the Criminal Procedure Code, conflicts can be resolved in 30 working days, or 45 working days at the latest.

Moreover, they are confidential, because the agreements that are made in a private session, with the presence of a mediator or a conciliator and the parties involved in the problem in a non-adversarial climate, recognizing past events, but they are encouraged to seek solutions in order not to feel that one has won and the other lost as usually happens in the mixed system, but both have received benefits from the decisions they agreed. They also have the advantage of having flexible agreements that can be modified if there is a settlement between the parties.

Among the alternative means of conflict resolution, we can analyze the conciliation and mediation as described in the Criminal Procedure Code for the State of Yucatán.

\section{Settlement}

The word "settlement" derives from the Latin word "conciliation" or "reconciliation." It is the action and effect of reconciling.

According to Peña (2010b), conciliation is "a legal act by which the parties come motuproprio, i.e., voluntarily, to a duly accredited third party, a conciliator, in order to help them solve a conflict of interest and thus, achieve social peace in justice" (p. 325).

Elvira Martinez Coco for her part said, "Reconciliation is a legal act, understood as the manifestation of the will of those participating in the conciliation and aimed at solving their conflict of interest" (Peña, 2010b, p. $325)$.

We can say that the settlement is an alternative means of conflict resolution, through which the parties are involved in proceedings in order to solve the conflict with the help of a third party called conciliator.

The role that the conciliator plays is to work with the parties in conflict in order to find a solution that is beneficial to both, even proposing formulas for a solution. The conciliator must help each party to better analyze alternative solutions, but without losing its status as impartial and leaving the resolution to the will of those involved in the conflict.

The aim of conciliation is that the parties in conflict resolve their differences voluntarily with the help of a third party called the mediator, who will propose solutions, will promote dialogue encouraging a rapprochement between them, and will guide them so they can resolve their conflict if they wish. To reach a solution, participants sign an agreement, which is in the nature of a contract (Constantino, 2009, p. 98). 
According to Peña (2010a, pp. 12-13), the reconciliation presents particular characteristics that clearly define mediation:

1. It is a legal act through which the parties rely on a third party to help them resolve a dispute;

2. It requires the existence of a third party, who does not decide; it merely points out the possible ways to resolve the conflict without the parties necessarily having to choose one;

3. It is an alternative dispute resolution mechanism, as the parties can decide whether to accept or not to undergo it;

4. The oral nature of the procedure and immediacy are always present, it is unimaginable a conciliatory process by written documents that come and go;

5. It takes place outside the judicial process;

6. It is voluntary, because the parties freely come to a mediation center and have no obligation to obey it;

7. It is confidential because the parties and the mediator must keep confidential all matters discussed and agreed;

8. It is very personal, because they are the conflicting parties involved and not their representatives;

9. It promotes a consensual solution to the conflict with the help of the conciliator;

10. The mediator does not resolve but facilitates negotiation and it is the parties that solve the conflict.

\section{Mediation}

Mediation is a non-adversarial process in which a third party assists the parties to negotiate and reach mutually acceptable agreements. The parties involved in a conflict seek a solution to their problems with the help of a third party called the mediator. The mediator guides the process, but does not suggest ways of solution, only helps the parties to create their own solutions. The purpose of the mediation, according to Peña (2010a), is to help the parties to generate their own solutions to resolve the conflict. The mediator guides the process, but does not suggest ways of solution (Peña, 2010b, p. 9).

For the Advisory Committee for Mediation Project in Mexico sponsored by the Rights Consortium, mediation is a voluntary, confidential, and flexible procedure to help two or more people or institutions find the solution to a conflict in non-adversarial manner, governed by principles of fairness and honesty, which involves a neutral and impartial third party called the mediator.

The main function of the mediator is to facilitate communication between participants in a conflict, making it possible for everyone to be heard fully, creating an atmosphere conducive for parties feel comfortable talking to each other, and focusing on their needs and interests to end their dispute peacefully, satisfying, and in a lasting way, without having the mediator imposing a solution.

Principles of mediation. In Mexico, part of the success of mediation programs is the application of the principles governing the process developed by the Advisory Committee Mediation Project, sponsored by the Rigths Consortium, which was approved by the Advisory Committee on October 18, 2002, and had the support of representatives of judiciaries, prosecutors' offices, universities, the Supreme Court of Justice of the Nation, the Mexican Mediation Institute, among others. According to Fierro (2010, pp. 28-30), these principles are as follows:

1. Voluntary: The participation of the parties in the mediation process must be by choice, not obligation. The mediator must recognize that they have the power to make decisions in the mediation.

2. Confidentiality: Anything discussed in mediation cannot be disclosed by the mediator, with the exception of cases where the information concerns a criminal offense as stated by the relevant legislation. The 
mediation sessions are held in private and the confidentiality involves the mediator and parties and everyone connected to the process.

3. Flexibility: The mediation procedure shall lack all strict formality in order to meet the particular needs of the parties. The mediation procedure is conducted without procedural formalities, where the mediator and the parts can decide how the mediation will take place.

4. Neutrality: The mediator maintains a posture and mentality of not giving in to his/her own inclinations and preferences throughout the process of mediation. Nor can induce the parties towards a solution, but must subtract his/her views related to the conflict and respect the decisions taken by them.

5. Impartiality: The mediator will act free of favoritism, bias, or rituals, trying the parties with absolute objectivity, without making any difference. The mediator must contain their natural sympathy or liking towards certain ideas, situations or people impulses and apologize if there are certain links between him/her and one or more of the parties.

6. Equity: The mediator must ensure that the agreement reached by the parties is understood and to that is perceived just and lasting for them, creating conditions of equality for the parties to achieve beneficial agreements for both.

7. Legality: It can only be mediated disputes arising from the rights that are freely available by the parties. When the mediator detected or suspected agreements that are based on false information or bad faith, he/she should recommend the parties seek professional or personal advice, because the agreements reached by them must be law-abiding.

8. Honesty: The mediator should disqualify himself/herself from participating in mediation or terminate it if, in his/her opinion, believes such action would be in favor of the interests of one of the parties.

Characteristics of mediation. According to Peña (2010b, pp. 10-11), like conciliation, mediation has certain features as follows:

1. To choose or elect a mediator or a third party is a mission that should rest with a person who possesses the necessary skills to find solutions to a problem that the parties cannot resolve.

2. It is an intermediate system of dispute resolution between conciliation and arbitration;

3. The process achieves acceptance by the parties through the proposal of a third party, which only has the power of recommendation;

4. The mediator does not impose anything, and his/her presence and work does not restrict or limit the initiative of the parties themselves to achieve the direct solution to the conflict;

5. The third person, despite having no authority over the decision itself, can assist the parties in the process of adopting the decisions, acting as a catalyst between them.

It should be noted that, in many cases, the application of these alternative methods of dispute resolution is more appropriate to resolve the disagreements between the parties, rather than a prison sentence, since it often not financially compensates the victim. So, the victim could feel that the time and effort invested in the struggle trying to obtain the respect for his/her rights would not be met adequately, remaining with a hint of frustration and resentment towards the defendant and the criminal justice system.

The benefits of implementing alternative methods of dispute resolution, such as conciliation and mediation, are not only for the parties involved in the conflict, who can resolve their disputes more quickly and satisfactorily than in a court proceeding. Benefits also fall to the lawyers, as their job opportunities are extended and can address more cases in less time, which will result in an increase in their income, and avoid personal and 
professional wear for a lengthy litigation. The judicial system also benefits by having less workload when the parties solve their disputes through agreements, because it is case that is not going to be part of litigation, allowing cost savings in infrastructure and personnel (Peña, 2010 a).

Besides the above alternative means, the procedural code for the State of Yucatán states that the imputed compensation agreements are also an alternate exit under which, the accused and the offended agree to satisfactory forms of reparation that have arisen as a result of a punishable act. As González (2016) stated, by means of compensation agreements between the victim and the accused or injured party, it can result in a settlement of the dispute through any suitable mechanism which has the effect of completing the procedure.

There is also the suspension of the proving process, which is a mechanism that allows either to the accuser or the suspects' prosecutors, with the consent of the victim or offended and with the approval of the supervisory judge, to give early termination to the procedure and leave it suspended as long as certain requirements of the code are met.

\section{Conclusion}

Alternative means of settling disputes constitute one of the pillars of restorative justice, and are designed to solve those conflicts that occur in a globalized and developed society, because the criminal proceedings are an exception to the controversy that has not been resolved. Thus, alternative mechanisms are necessary to find appropriate solutions when a conflict occurs, or when there exist a victim and a victimizer, not using or proposing them by the authorities, it would be the denial of a human right, because all authority should look above all for a culture of peace.

\section{References}

Constantino, R. C. (2009). Introducción al estudio sistemático del Proceso Penal Acusatorio (Introduction to the systematic study of the Adversarial Criminal Procedure) (2nd ed.). México: MaGister.

Gobierno Federal (Mexican Federal Government). (1917). Constitución Política de los Estados Unidos Mexicanos. Retrieved from http://www.diputados.gob.mx/LeyesBiblio/htm/1.htm

Gobierno del Estado de Yucatán (Yucatan State Government). (2011). Criminal procedure code for the State of Yucatan. Autor.

González, D. C. (2016). Manual práctico del juicio oral (Practical manual of the trial). México: Tirant lo Blanch.

Gorgón, F., \& Pesqueria, J. (2015). La ciencia de la mediación (The science of mediation). México: Tirant lo Blanch.

Fierro, A. E. (2010). Manejo de conflictos y mediación (Conflict management and mediation). México: Oxford University Press.

Peña, O. (2010a). Mediación y conciliación extrajudicial (Mediation and conciliation settlement). México: Flores Editor y Distribuidor.

Peña, O. (2010b). Técnicas de litigación oral (Oral litigation techniques). México: Flores Editor y Distribuidor.

Sánchez, A. (2015). Mediación y arbitraje (Mediation and arbitration). México: Tirant lo Blanch. 